\title{
Comparison of Egg Quality Characteristics of Different Poultry Species
}

\author{
W. M. R. M. Wijedasa ${ }^{1}$, Y. H. S. T. Wickramasinghe ${ }^{1}$, J. K. Vidanarachchi ${ }^{1} \&$ S. M. C. Himali ${ }^{1}$ \\ ${ }^{1}$ Department of Animal Science, Faculty of Agriculture, University of Peradeniya, Peradeniya, Sri Lanka \\ Correspondence: S. M. C. Himali, Department of Animal Science, Faculty of Agriculture, University of \\ Peradeniya, Peradeniya 20400, Sri Lanka. Tel: 0094-710-666-607. E-mail: chimali@pdn.ac.lk; \\ himali.samaraweera@gmail.com
}

Received: February 8, 2019

doi:10.5539/jas.v12n11p331

\author{
Accepted: September 13, $2020 \quad$ Online Published: October 15, 2020 \\ URL: https://doi.org/10.5539/jas.v12n11p331
}

\begin{abstract}
This study was conducted to compare external and internal quality attributes and some functional property parameters of eggs from five different poultry types/species namely, Sri Lankan village chicken \& commercial chicken (Shaver brown), duck (Vigoa), quail (Japanese quail) and turkey (Turkey white). In addition, the impacts of cold storage $\left(10^{\circ} \mathrm{C}\right)$, on commercial chicken eggs and Sri Lankan village chicken eggs, over a period of three weeks were evaluated. Yolk color, shape index, egg weigh and shell thickness values of the freshly laid eggs were significantly difference among the four species $(P<0.05)$. Yolk color of the village chicken egg was 7.30 which is significantly higher $(P<0.05)$ than that of other species. Quail egg had the highest $(P<0.05)$ shape index value $(80.90 \pm 0.01)$ and the lowest egg weight $(9.47 \pm 5.64 \mathrm{~g})$. Whereas, turkey egg had the lowest $(P<0.05)$ shape index value $(69.20 \pm 0.02)$ and the highest egg weight $(71.48 \pm 5.21 \mathrm{~g})$. Village chicken eggs and quail eggs had significantly lower $(P<0.05)$ eggshell thickness than that of other poultry species. The lowest eggshell thickness $(0.008 \pm 0.00 \mathrm{~mm})$ was shown by quail eggs. Duck egg white had the highest $(P<0.05)$ viscosity and foam stability whereas, commercial egg had the lowest viscosity. Further, internal quality and functional quality traits from Sri Lankan village chicken eggs and Shaver brown eggs were decreased with the increasing storage period ( 3 weeks) at $10^{\circ} \mathrm{C}$. Quail egg has the highest shape index and duck egg white has the highest viscosity and foam stability. Some of the egg quality traits are significantly affected by type/species of the bird and the storage time.
\end{abstract}

Keywords: chicken, duck, egg quality, quail, refrigerated storage, turkey

\section{Introduction}

Eggs from birds such as chicken, duck, goose and quails are the most common and versatile food items since prehistoric period (Song, Choi, \& Oh, 2000). The egg is inexpensive and a well-balanced food source of high quality nutrients among many nations of the world (Xu, Jai, Luo, Yu, Dai, \& Li, 2018). Currently, considering the global level, it is one of the fast growing animal industries (The Poultry Site, 2015). Furthermore, poly functional attributes such as coagulation, foaming, emulsification colorant and anti-crystalizing properties are commercially important in modern food industry (Liu, Jang, Kim, B. D. Lee, M. Lee, \& Jo, 2009). These functional properties are commonly used in the food industry (Chang \& Chen, 2000).

Chicken egg is the almost expulsive egg industry in the world and information on eggs is mostly limited to the chicken eggs (Song et al., 2000). However, non-hen eggs such as duck, goose, and quail eggs are produced for human consumptions in some parts of the world (Dudusola, 2010). Usually eggs are marketed as shelled eggs. However, in recent decades egg-processing industry has grown and, there is considerable demand for hen egg products (Linden \& Lorient, 1999). Global egg production has increased during past few years (Food and Agricultural Organization Statistics (FAOSTAT, 2015). In 2018, laying flock of hens produced 7,466,460 tons of eggs worldwide. According to the FAOSTAT (2020), China is the world largest egg producer and followed by United State, Japan, Russian Federation, Mexico and Brazil. However, 80\% of egg production in China occupied on small-scale backyard family-type systems. Moreover, from 1995 to 2005 percentage of global chicken egg production has increased by $39 \%$ and, other eggs (non-hen eggs) have increased by $27 \%$. However, more than $90 \%$ of the global egg production comprises of hen eggs and only remaining percent is from non-hen eggs. Meanwhile, $80 \%$ of the total chicken populations are found in village poultry production system in the 
worldwide. In Sri Lankan context, poultry industry is the most developed sector among the livestock sector. The per capita availability of eggs among Sri Lankan consumers was 120.25 eggs in 2019 (Department of Animal Production and Health, 2020). Backyard village chicken production contributes $15 \%$ to the national egg production in Sri Lanka. However, only little amount of duck eggs is produced in the country. According to DAPH (2015) of Sri Lanka, the duck population in 2014 was 11,850 in numbers.

Standards for egg quality are based on several internal and external quality parameters. These quality parameters depend on various factors (USDA Egg Grading Manual, 2000). Egg quality is defined as the characteristics of egg, which affect for consumer acceptability. Moreover, based on these quality parameters many egg-grading methods have been developed worldwide (USDA, 2000; Dudusola, 2010). Among external characteristics; cleanliness of shell, soundness of eggshell, shape, egg weight, shell weight and freshness are the most important characteristics in marketing and preservation of eggs (Hrncar et al., 2014). Internal factors and functional quality parameters such as relative viscosity, foaming, gelling, yolk index, Haugh index, and chemical composition, firmness, free from foreign matters in yolk and albumen are important for egg products industry (Duan et al., 2018; Sheng et al., 2018).

With the development of world egg industry, it has been identified a rising trend to produce and consume other poultry egg including duck, quail and turkey due to their desirability as a source of food. According to statistical data released by Food and Agricultural Organization (FAO) in 2013, it was shown that world production of non-hen eggs had been increased from $6.57 \%$ (1991) to 7.63\% (2009). Eggs from most of poultry species have similarities with regard to internal and nutritional composition (Dudusola, 2009). In Sri Lankan context, commercial chicken egg is the major poultry egg, which is consumed. Furthermore Sri Lankan village chicken, quail and duck eggs are also consumed in small quantities (DAPH, 2015). However, information related to non-hen eggs for example, village chicken eggs are very limited especially the quality parameters (Elango \& Mahendrarasa, 2013).

Hence, the main purpose of this study was to assess and compare the internal, external and functional attributes of eggs from four different poultry species namely, Sri Lankan village chicken \& commercial chicken, duck, turkey and quail. Further, the research was carried out to evaluate the effect of refrigerated storage $\left(10^{\circ} \mathrm{C}\right)$ on both internal and external quality traits and functional characteristics of village chicken eggs and commercial chicken eggs.

\section{Materials and Methods}

The commercial chicken eggs (Shaver Brown) were purchased from a commercial layer farm in Kandy district, Sri Lanka. Whereas, turkey (Turkey white), duck (Vigoa) and quail (Japanese quail), eggs were collected from Livestock Field Station, Department of Animal Science, University of Peradeniya, Peradeniya, Sri Lanka. Above mentioned poultry species were managed under intensive production system. Village chicken eggs were collected from Uda Peradeniya village, Kandy, Sri Lanka where scavenging village chickens are reared under free-range conditions.

Freshly laid, 60 Shaver brown eggs, 60 village chicken eggs, 40 quail eggs, 15 duck eggs and turkey eggs were used to asses quality parameters. Quality evaluation was conducted with 15 eggs from each of commercial chicken, village chicken, duck, turkey and quail eggs. Whereas, Shaver Brown eggs and village chicken were labeled and stored under refrigerated conditions $\left(10^{\circ} \mathrm{C}\right)$ on plastic egg trays for a period of three weeks and, quality parameters were measured in $0,1^{\text {st }}, 2^{\text {nd }}$ and $3^{\text {rd }}$ week of storage. Weekly, 15 of eggs from each commercial and village chicken stored were used to evaluate the external, internal and functional quality parameters.

\subsection{External Egg Quality Parameters}

Individual eggs were weighed accurately to nearest $0.01 \mathrm{~g}$ using an electronic balance (Model PA313, Ohaus Crop., Pine Brook, NJ, USA). Steel Vernier caliper (General Tools \& Instruments, New Yolk, USA) was used to determine the length and width of individual eggs. Width from blunt end, middle and upper end were taken and average of the three measurements was recorded as the width of an egg in centimeter. Shape index (SI) was then calculated according to following formulation (No. 1), that has been previously described by several scholars (Anderson, 2004).

$$
\text { Shape Index } \%=\frac{\text { Width of egg }(\mathrm{mm})}{\text { lenght of egg }(\mathrm{mm})} \times 100
$$

To find out the shell thickness, eggs were broken into two halves and the egg content was removed. Shells were wiped with tissue paper and kept upside down to drain out the remaining albumen. Once eggshells were dried, 
three repeated measures were taken from three different places (middle and each two ends) by using a Vernier caliper (General Tools \& Instruments, New Yolk, USA). The average of the three measurements was recorded as the thickness of the shell with membrane in millimeter.

\subsection{Internal Quality Parameters}

After weighing of eggs, the eggs were broken out onto a balanced flat glass tray to assess the internal quality parameters namely, albumen height, yolk height, yolk width, yolk color, Yolk Index (YI) and Haugh Unit (HU). Egg yolk color was examined by using yolk color fan (ROCHE, Yolk Color Fan, Switzerland) and the most appropriate color number was given accordingly. Diameter of the yolk was measured by using a steel Vernier caliper (General Tools \& Instruments, New Yolk, USA). Three measurements of diameter were taken and average diameter was recorded in millimeter. After the egg was broken into flat glass surface, a tripod micrometer (Model S-6428, B.C. Ames Co., Waltham, Mass, USA) was placed over the egg and the pointer was lowered carefully until it just touches the yolk. Value displayed on the panel was recorded as the yolk height in millimeter. Height from three places in the yolk was recorded. Three measurements were averaged and taken as the height of the yolk. Albumen heights of the thick albumen were measured using tripod micrometer according to the method described in United States Department of Agriculture (USDA) Egg Grading Manual (2000).

The egg yolk index (YI) was determined according to following formulation (No. 2) that has been described by Funk (1948) and Eke et al. (2013).

$$
\text { Yolk Index }=\frac{\text { Average height of yolk }(\mathrm{mm})}{\text { Averge diameter of yolk }(\mathrm{mm})}
$$

The Haugh Unit (HU) was determined according to the following formulation (No. 3), that was firstly described by Haugh (1937).

$$
\mathrm{HU}=100 \log \left(\mathrm{H}-1.7 \mathrm{~W}^{0.37}+7.57\right)
$$

Where, $\mathrm{H}$ was height of thick albumen in $\mathrm{mm}$ and $\mathrm{W}$ was weight of egg in gram.

\subsection{Measurement of Functional Properties}

The gelling strength was determined according to the method described by Tan et al. (2012) with some modifications. Homogenized (one minute at $12,000 \mathrm{rpm}$ speed with Nissi BM-4 homogenizer) whole egg samples $(30 \mathrm{~g})$ were poured into $50 \mathrm{~mL}$ beakers, which were covered with aluminum foil. Samples were placed into a preheated water bath at $85{ }^{\circ} \mathrm{C}$ for $30 \mathrm{~min}$. Samples were then removed from the water bath and cooled to room temperature $\left(28{ }^{\circ} \mathrm{C}\right)$. Gel samples were removed from the beakers and cut into $3 \mathrm{~cm}$ diameter and $1.5 \mathrm{~cm}$ height cylinder. Tensile properties were measured using Universal Instron Machine (Instorn Model 4456, USA). Two $\mathrm{kN}$ load was used to determine the gel strength under a speed of $150 \mathrm{~mm} / \mathrm{min}$. The maximum force $(\mathrm{N})$ was determined when plunger had penetrated $10 \mathrm{~mm}$ into the gel cube. For the measurement of viscosity, $50 \mathrm{~mL}$ of whole liquid egg samples were taken into a concentric cylinder. Brookfield viscometer (Model BL, Tokimec Inc., Tokyo, Japan) was used with number 02 spindle to measure viscosity of egg sample. The International Commission on Illumination (CIE, Commission internationale de l'éclairage) $\mathrm{L}^{*} \mathrm{a} \mathrm{b}^{*}$ values for lightness $\left(\mathrm{L}^{*}\right)$, redness/greenness $\left(a^{*}\right)$ and yellowness/blueness $\left(b^{*}\right)$ were measured in fresh whole egg using a Color Reader CR-10 (Konica Minolta Sensing, Tokyo, Japan). Each measurement was repeated five times and the average values were calculated. The $\Delta \mathrm{E}^{*}$ value was recorded as the total color of the whole egg sample.

\subsection{Statistical Analyses}

Complete Randomized Design (CRD) was used as experimental design. The data were analyzed using General Linear Model (PROC GLM). Treatment means were separated using Duncan's Multiple Range Test using SAS 9.1 software package (SAS Institute Inc., 2009).

\section{Results and Discussion}

\subsection{Comparison of Village Chicken, Shaver Brown, Duck, Turkey and Quail Eggs}

The highest average HU was recorded from quail eggs (81.46 \pm 1.43$)$ whereas the lowest HU was recorded with turkey eggs (70.53 \pm 2.97$)$ among selected poultry species (Table 1). Village chicken eggs also showed significantly high $(P>0.05) \mathrm{HU}$ value. The HU value of freshly laid egg ranges from $72-110$. With the storage time HU value decreased. High HU value indicates high albumen quality (USDA, 2000). Eke et al. (2013) reported that HU value of freshly laid egg was 79. Freshly laid eggs were used to assess the HU values in this study. Therefore, it can be suggested that due to freshness of the egg, HU of the tested eggs were high (Musa et al., 2011). Further, Tadesse et al. (2015) showed similar HU value (79.26) for village chicken eggs. According to the Cieck and Kartalkanat (2009), HU value for village chicken eggs and commercial chicken eggs were 85.82 
and 82.64, respectively. Further, scholars have discussed that with the age of the bird, the albumen quality can be decreased. Song et al. (2000) showed that HU variation could be due to different of spices, nutritional quality, seasonal changes and stocking density of poultry birds. In agreement with these factors, variations in HU values among different poultry species can be seen in the present study. Hrncar, Hanusova, Hanus, and Bujko (2014) reported that HU values of laying type and meat type Japanese quail were 87.28 and 87.58, respectively. Comparably, in this study quail egg showed significantly high HU value (81.46 \pm 1.43 ). Hrncar et al. (2014) reported high HU value $(81.46 \pm 1.43)$ of Japanese quail eggs similar to current study due to species similarity as well as freshness of the egg.

The yolk indices ranged from $0.42 \pm 0.01$ (duck eggs) to $0.40 \pm 0.02$ (quail eggs) across the selected species (Table 1). The YI of quail was significantly lower $(P<0.05)$ than that of Shaver brown and duck eggs. Dudusola (2009) investigated that YI of freshly laid quail egg was 0.40 as similar as to the present study. It has been reported that the yolk index of quail eggs has been ranged between 0.46 to 0.6 (Marzec, Michalczuk, Damaziak, Mieszkowska, Lenart, \& Niemiec, 2016). Kokoszynski, Bernacki, and Korytkowska (2007) reported that yolk index of Peking duck at the beginning of laying period was 0.41 . The present study revealed that yolk index of Vigoa duck egg as $0.42 \pm 0.01$. The egg yolk of the freshly laid egg is round and spherical in shape. Yolk index is the ratio of egg yolk height to its width. The integrity of the egg yolk depends on strength of its vitelline membrane (Samli et al., 2005; Zita et al., 2009; Eke et al., 2013). Egg yolk quality depends on many factors such as age of the bird, storage time, breed of the bird, variation of bird strain, and nutritional quality (Song et al., 2000; Samli et al., 2005; Zita et al., 2009). According to Zita et al. (2009), yolk index of eggs from ISA brown, Hisex brown and Moravia BSL were affected by the hen age and genotype. In addition, Nowaczewski et al. (2010) investigated that yolk index of Japanese quail egg was affected by age of the bird. Further, indicated that yolk index percentage of eggs collected from 9, 25 and 31 weeks aged bird were $49.18 \%, 48.60 \%$ and $47.67 \%$, respectively.

The highest mean yolk color value was recorded in village chicken eggs (7.30 \pm 0.02$)$. Whereas, the lowest mean yolk color was recorded in quail eggs $(4.30 \pm 0.01)$ (Table 1). Further, village chicken egg showed significantly higher $(P>0.05)$ yolk color than that of other poultry species. Quail eggs and turkey eggs showed significantly lower egg yolk color value. According to Hrncar et al. (2014), yolk color of the laying type quail and meat type quail was 4.30 and 4.40, respectively. Tadesse et al. (2015) reported that eggs from village chicken production system have deep egg yolk yellow color than eggs from intensive production system. Further, it indicates that the yolk color is mainly due to feed eaten by the hen. Furthermore, it explained, village chicken under backyard production system could get enough plant pigments (Xanthophyl, Carotenoids, and Cryptoxanthin etc.) which caused to increased yolk color. Especially, green grass intake during scavenging might have improved the yolk color of the village chicken eggs. Furthermore, Cieck and Kartalkanat (2009) showed that village chicken egg has significantly higher yolk color value (11.94) than that of commercial chicken eggs (7.8).

The highest average shape index value $(80.90 \pm 0.01)$ was recorded with quail eggs. Whereas, the lowest of (69.20 \pm 0.02 ) was observed in turkey eggs (Table 1). However, according to Hristakieva et al. (2017) study, SI value of North Caucasian Bronze turkey eggs collected from 34 weeks old and 46 weeks age hens were $74.25 \pm 0.49$ and $71.57 \pm 0.60$, respectively. According to the results of study, duck and quail, egg had significantly higher shape index values than turkey eggs. Generally, poultry egg shape is considered as oval shape. However, there is a little different among the poultry species (Song et al., 2000). Shape index of a standard egg is $74 \%$. Even if, the shape index of poultry egg can be decreased with the increase of bird's age (Song et al., 2000; Dudusola, 2010). However, Hrncar et al. (2014) investigated that laying type quail and meat type quail had shape index of $76.70 \%$ and $78.16 \%$, respectively. According to the Nowaczewski et al.'s (2010) study, SI of Japanese quail egg had no effect on birds 'age. Furthermore, researches have indicated that the SI value of eggs from 9, 25 and 31 weeks age bird were 79.0, 79.0 and 79.1, respectively and which is lower than the SI value of quail eggs observed in the current study. Nevertheless, according to Song et al. (2000) quail eggs had shape index of 78.93. Hussain et al. (2013) reported that shape indices for market chicken eggs, farm chicken eggs and indigenous chicken eggs were $81.20 \pm 0.85,80.21 \pm 0.98$, and $80.40 \pm 1.19$ respectively. Further, they indicated that the variation of shape index among different species might be due to their genetic differences and due to differences in management systems. Zita et al. (2009) found that there were no significant difference of SI among ISA brown, Hisex and Moravia BSL eggs and it was indicated that SI value vary with the hen age. Shape of an egg depends on genetic basis of bird, age of bird, season of the bird rearing and bird's diet (Nikolova \& Kocevski, 2006). Shape index of village chicken eggs was $74 \%$ in the current study. Despite to this, Elango and Mahendrarasa (2013) reported that Sri Lankan village chicken eggs have relatively low shape index value of $67.21 \%$. Also, they stated that shape index values of naked neck chicken, exotic chicken and exotic local chicken eggs were $72.67 \%, 79.21 \%$ and $73.43 \%$, respectively. 
Turkey eggs showed the highest shell thickness value $(0.13 \mathrm{~mm})$. Whereas duck and turkey eggs showed significantly higher shell thickness value than that that of village chicken and quail eggs (Table 1). In contrast to the present findings, Elango and Mahendrarasa (2013) reported that shell thickness values of village chicken, naked neck chicken, exotic chicken and exotic local chicken eggs were $0.52,0.53,0.49$ and $0.50 \mathrm{~mm}$, respectively. Shell thickness value of commercial chicken eggs was $0.10 \mathrm{~mm}$. Nevertheless, the shell thickness value of eggs collected from retailer market in Sri Lanka was $0.15 \mathrm{~mm}$ (Wickramasinghe et al., 2015). The quail eggshell thickness values from two companies were recorded as $0.157 \mathrm{~mm}$ and $0.153 \mathrm{~mm}$ (Nepomuceno et al., 2014). Further, they stated that eggshell of duck is very hard and not easily broken while handling, and though pore sizes of the duck egg are large, they are covered with protective mucus covering which prevents entry of microorganisms. Okruszek et al. (2006) reported shell thickness values of two different breeds of ducks as 0.67 $\mathrm{mm}$ and $0.65 \mathrm{~mm}$. According to nutritional composition analysis of Jalaludeen and Churchil (2006), it was observed that turkey egg contains $99 \mathrm{mg}$ of $\mathrm{Ca}$ and duck egg contains $64 \mathrm{mg}$ of $\mathrm{Ca}$ in $100 \mathrm{~g}$ of eggshell respectively. Gunarathne et al. (1993) found that scavenging village chicken contain $10.41 \%$ of plasma Ca level compared to commercial chicken plasma Ca level of $19.61 \%$. Whereas, Rodrigues et al. (2005) reported that dietary $\mathrm{Ca}$ which can be measured through blood $\mathrm{Ca}$ level increased eggshell thickness of chicken eggs. Furthermore, it was observed that excessive dietary $\mathrm{Ca}$ increased $\mathrm{Ca}$ deposits in the egg (Pelicia, 2009) which will support with the explanation of low Ca level of village chicken eggshell.

Turkey egg showed the highest mean weight $(71.48 \pm 5.21 \mathrm{~g})$, meanwhile quail egg showed the lowest mean egg weight. Moreover, significant effect of poultry species on egg weight was observed in the present study. However, more or less similar to the present study, Hristakieva et al. (2017) found that the egg weights of Turkey eggs obtained from 34 and 46 weeks age hen were $82.04 \pm 0.76 \mathrm{~g}$ and $84.22 \pm 0.78 \mathrm{~g}$ respectively, showing no significant effect on egg weight from the hen's age. Despite, Shaver brown eggs showed mean egg weight of $57.83 \pm 5.64 \mathrm{~g}$, similar to Zita et al. (2009). Furthermore, scholars have shown that with the increase of hen's age the egg weight also has increased and there were significant differences in egg weights among eggs from different strains of brown egg layers. Disagreeing with the mean egg weight value of village chicken eggs in the present study, Elango and Mahendrarasa (2013) have reported that the mean egg weight of Sri Lankan village chicken was $43.43 \pm 1.9 \mathrm{~g}$. The scholars have indicated that the low egg weight was due to low body weights of the village chicken hens. In addition, Monira et al. (2003) reported that the weights of eggs from Barred Plymouth Rock, White Leghorn, Rhode Island Red and White Rock as 64.00, 63.00, 57.20 and 57.00 g, respectively. The mean weight of quail eggs in the present study was $(9.47 \pm 5.64 \mathrm{~g})$. Alkan, et al. (2010) reported that of the mean weight of eggs from low body weight Japanese quails was $9.23 \pm 0.07 \mathrm{~g}$. The average weight of eggs collected from high body weigh quail line was $14.14 \pm 0.17 \mathrm{~g}$, and they have concluded that the weights of egg depend on the weight of the birds. In addition, Zita et al. (2013) found that the weights of quail eggs increase with the increase of the bird age, and the highest egg weight was recorded at the 25 weeks of bird's age. It is clear that, many factors such as poultry breed, strain, age of hen, nutrition level and climate affect to weight of freshly laid eggs (Zita et al., 2009; Elango \& Mahendrarasa, 2013; Zita et al., 2013; Hristakieva et al., 2017).

Table 1. Comparison of eggs from four poultry species (means \pm SD)

\begin{tabular}{llllll}
\hline Parameters & Village chicken egg & Shaver brown egg & Duck egg & Quail egg & Turkey egg \\
\hline HU & $79.86 \pm 1.39^{\mathrm{a}}$ & $75.94 \pm 1.40^{\mathrm{ab}}$ & $71.74 \pm 1.32^{\mathrm{b}}$ & $81.46 \pm 1.43^{\mathrm{a}}$ & $70.53 \pm 2.97^{\mathrm{b}}$ \\
Yolk Index & $0.41 \pm 0.02^{\mathrm{ab}}$ & $0.41 \pm 0.01^{\mathrm{a}}$ & $0.42 \pm 0.01^{\mathrm{a}}$ & $0.40 \pm 0.02^{\mathrm{b}}$ & $0.40 \pm 0.02^{\mathrm{ab}}$ \\
Yolk Color & $7.30 \pm 0.02^{\mathrm{a}}$ & $6.00 \pm 0.02^{\mathrm{b}}$ & $6.00 \pm 0.02^{\mathrm{b}}$ & $4.30 .01 \pm 0.01^{\mathrm{c}}$ & $4.30 \pm 0.01^{\mathrm{c}}$ \\
Shape Index & $74.50 \pm 0.02^{\mathrm{b}}$ & $74.50 \pm 0.02^{\mathrm{b}}$ & $75.80 \pm 0.01^{\mathrm{a}}$ & $80.90 \pm 0.01^{\mathrm{a}}$ & $69.20 \pm 0.02^{\mathrm{c}}$ \\
Shell Thickness (mm) $_{\text {Egg weight }(\mathrm{g})}^{0.09 \pm 0.01^{\mathrm{b}}}$ & $0.10 \pm 0.01^{\mathrm{ab}}$ & $0.12 \pm 0.01^{\mathrm{a}}$ & $0.08 \pm 0.01^{\mathrm{b}}$ & $0.13 \pm 0.01^{\mathrm{a}}$ \\
\hline
\end{tabular}

Note. ${ }^{\mathrm{a}-\mathrm{c}}$ Means with different superscripts in the same row were differ significantly $(P=0.05)$.

Village chicken egg, duck and commercial chicken egg had significantly higher $(P<0.05)$ gel strength than other two species (Figure 1). Quail eggs had the lowest and duck egg had the highest $(P<0.05)$ gel strength than other species. Egg gel is formed due to changes in the protein structure. Changes in structure of egg protein lead to coagulate the egg protein (Tan et al., 2012). According to Houška et al. (2004), egg white gel strength increased with the egg white concentration. Hence the highest gel strength in fresh duck eggs can be due to high amount of albumin present especially when compared with chicken egg (Jalaludeen \& Chutchil, 2006). Gel strength depends on other factors including $\mathrm{pH}$ and temperature (Chang \& Chen, 2000). It increases with the 
increasing $\mathrm{pH}$. The gel strength is decreased with the increasing storage period (Hammershøj et al., 2002). Apart from these factors, housing system and hen age also significantly affect the gel strength and hardness (Hammershøj et al., 2002; Alamprese et al., 2012).

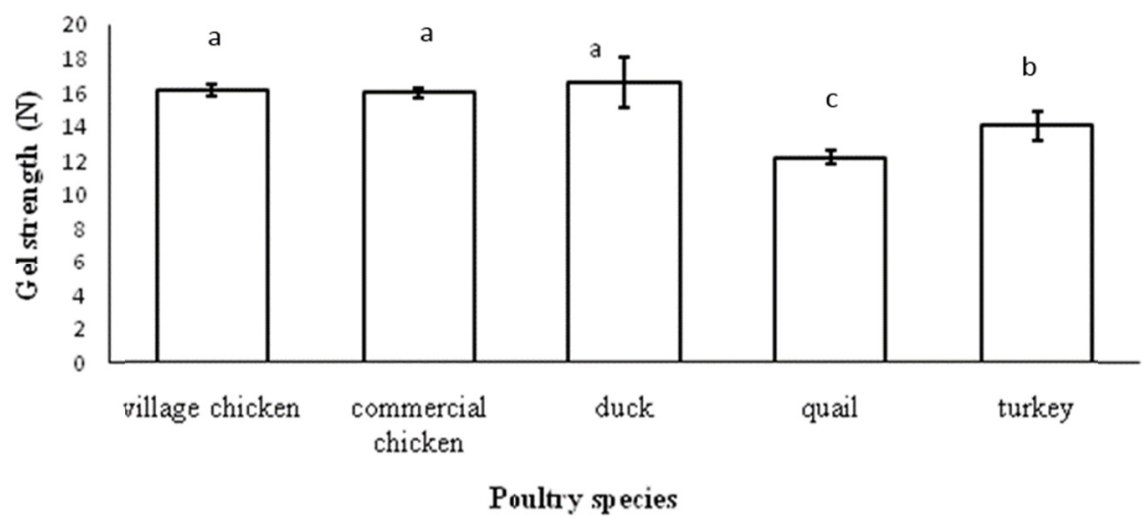

Figure 1. The gel strength of whole egg of different poultry species

Duck eggs had significantly high viscosity values. Whereas, Shaver brown (commercial egg) had significantly low viscosity values compared to other poultry species (Figure 2). This can be possible due to high content of albumen (60\% albumen of total egg weight), which creates thick and firm structure in duck egg white (Jalaludeen \& Churchil, 2006). Rheological quality of liquid is referred to as the slope of the shear stress versus shear rate curve. Ovalbumin is the major egg white protein (54\% of egg white protein) that plays a vital role with regard to rheological properties of egg white. The albumen viscosity depends on ovomucin-lyzozyme complex. Therefore, decrease of albumen viscosity is due to destabilization of ovomucin-lysozyme structure. Moreover, that ovomucin complex destabilization depends on many factors such as storage period, temperature and $\mathrm{pH}$ (Spada et al., 2012). The viscosity is an important quality attribute for egg whipping, gelling and emulsifying qualities (Yuceer \& Caner, 2014). Scholars found that the albumen viscosity of chicken egg was $58.57 \pm 2.34 \mathrm{mPa}$, which is higher than the viscosity value of the Shaver brown chicken eggs found in the present study. According to the Kumbár et al. (2015), among chicken, goose and quail eggs, the highest apparent viscosity was observed with goose eggs and the minimum was recorded with quail eggs. The chemical composition of eggs of different species of poultry resulted differences in rheological properties of whole egg liquids (Kumbár et al., 2015). However, comparison of viscosity with the other literature available is somewhat different due to use of different sample preparation methods and differences in shear rates used for the assays (Lucisano et al., 1996; Spada et al., 2012; Yuceer \& Caner, 2014).

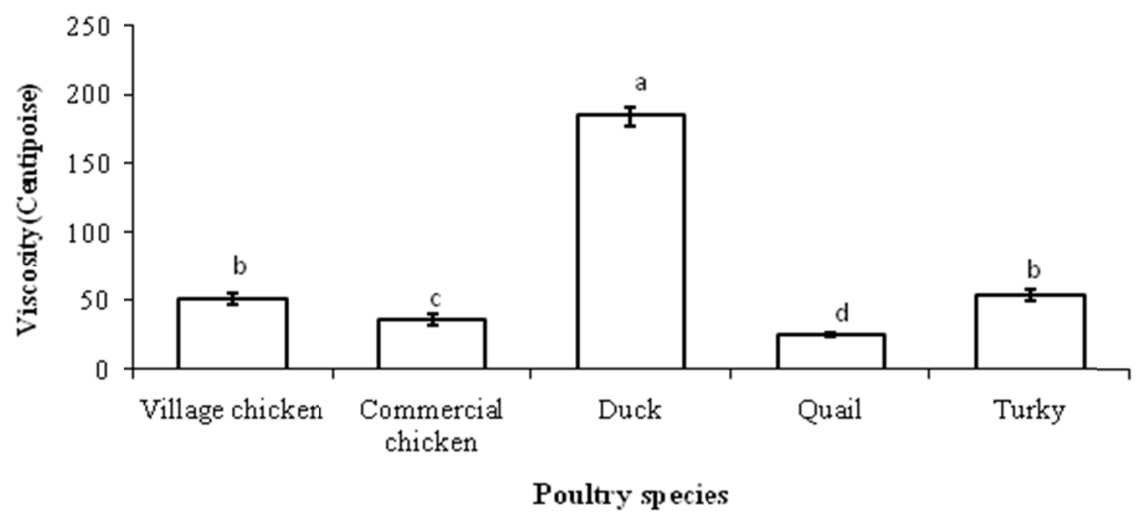

Figure 2. Viscosity values of whole egg of different poultry species 


\subsection{Effect of Storage Condition on Egg Quality of Village Chicken Eggs and Shaver Brown Eggs}

Haugh unit values have shown a decreasing trend with increasing storage time. However, there was no significant difference found between two types of chicken eggs with increasing storage time. During 0 and $1^{\text {st }}$ week, HU values of Shaver brown eggs were significantly higher than that of village chicken eggs (Table 2). However, eggs from both Shaver brown and village chicken at the second and third week were not different. Haugh unit was proposed by Haugh (1937) based on thick albumen height and weight of the egg. HU is a good parameter for describing the egg quality (albumen quality) and $\mathrm{HU}$ value decreases with the storage time and temperature (Samli et al., 2005). Further, reduction of $\mathrm{HU}$ is due to increase of $\mathrm{pH}$ of the egg. The $\mathrm{pH}$ of a freshly laid egg is around 7.6-7.9 and increases up to about 9.7 due to loss of $\mathrm{CO}_{2}$ from the egg with temperature dependent manner. Moreover, increase of $\mathrm{pH}$ in the egg results thick albumen to become watery that leads to decrease albumen quality (Benton \& Brake, 2000). Similar to present study, Yuceer and Caner, (2013) observed that $\mathrm{HU}$ values of uncoated eggs that stored under ambient temperature (HU 85.04 \pm 0.14 ) were decreased to $73.10 \pm 0.70$. Raji et al., 2009 , reported that eggs stored under $32{ }^{\circ} \mathrm{C}$ for 28 days showed drastically reduction of the $\mathrm{HU}$ values from $83.37 \pm 8.8$ to $34.0 \pm 6.0$ agreeing with the results of the present study.

Mean YI values were decreased $(P<0.05)$ with the increasing storage period at $10{ }^{\circ} \mathrm{C}$ in both village and commercial chicken eggs. However, there was no significant difference found $(P>0.05)$ between yolk indices of two groups during the refrigerated storage period (Table 2). Spherical shape of egg yolk can be expressed by yolk index. It is an indication of freshness of eggs. Yolk index was calculated by using the height of yolk and width of yolk (Stadelman, 1977b). High yolk index value represents the high yolk quality (Wardy, 2010). Akyurek and Okur (2009) stated that during storage of the egg, egg yolk absorbs water from albumen and expansion of the yolk causes to reduce the strength of vitelline membrane that results in flattening of the egg yolk. The results of the present study are agreed with the results of Samli et al. (2005). The egg yolk index decreased from 44.09 (Fresh egg) to 39.02 over the storage period of 10 days at $21{ }^{\circ} \mathrm{C}$. Yuceer and Caner (2014) have reported similar trend of reducing YI from $0.48 \pm 0.00$ to $0.28 \pm 0.01$ during 6 weeks of storage period. Kneer et al. (2006) stated that the temperature of storage and the age of the hen have affected the strength of vitelline membrane. Similar to the present findings, Cieck and Kartalkanat (2009) reported that yolk indices of village chicken and commercial eggs were 0.45 and 0.43 , respectively. Further, they stated that there was no significant difference found in yolk indices among village chicken eggs and commercial chicken eggs.

Shape indices of both village and commercial chicken eggs were remained unchanged during the storage period (Table 2). Similar to this, Alsobayel and Albadry (2010) reported that shape index of eggs remained unchanged. Shape index is the ratio between the width and length of an egg. There is a natural variability in egg shape. However, shape of an egg depends on genetic basis of bird, age of bird, season of the bird and bird diet (Nikolova \& Kocevski, 2006). Shape index value less than 74 is considered as sharp eggs whereas shape index value between 72-76 and more than 76 are consider as normal (Standard) and round, respectively (Altuntas \& Sekeroglu, 2008). Tabidi (2011) investigated that, SI value remain unchanged during storage period either in refrigerated storage or room temperature. In addition to this, Raji et al. (2009) explained that SI value was not affected by either storage period or storage temperature.

Table 2. Effect of storage on internal and external egg quality of village chicken eggs and commercial chicken eggs (Means \pm SD)

\begin{tabular}{llllll}
\hline Storage Duration & & HU & Yolk Index & Shape Index & Shell Thickness \\
\hline \multirow{2}{*}{ Freshly Laid eggs $(0$ week) } & Village chicken egg & $79.68 \pm 1.10^{\mathrm{a}}$ & $0.41 \pm 0.04^{\mathrm{a}}$ & $74.5 \pm 0.02^{\mathrm{a}}$ & $0.09 \pm 0.01^{\mathrm{a}}$ \\
& Commercial egg & $75.94 \pm 1.46^{\mathrm{b}}$ & $0.42 \pm 0.05^{\mathrm{a}}$ & $74.5 \pm 0.02^{\mathrm{a}}$ & $0.10 \pm 0.01^{\mathrm{b}}$ \\
\hdashline $1^{\text {st }}$ week & Village chicken egg & $73.99 \pm 1.01^{\mathrm{a}}$ & $0.41 \pm 0.00^{\mathrm{a}}$ & $75.8 \pm 0.03^{\mathrm{a}}$ & $0.09 \pm 0.01^{\mathrm{a}}$ \\
\hdashline & Commercial egg & $71.44 \pm 1.46^{\mathrm{b}}$ & $0.41 \pm 0.05^{\mathrm{a}}$ & $76.1 \pm 0.01^{\mathrm{a}}$ & $0.10 \pm 0.00^{\mathrm{b}}$ \\
$2^{\text {nd }}$ week & Village chicken egg & $70.57 \pm 0.58^{\mathrm{a}}$ & $0.39 \pm 0.02^{\mathrm{a}}$ & $75.1 \pm 0.02^{\mathrm{a}}$ & $0.09 \pm 0.01^{\mathrm{a}}$ \\
\hdashline & Commercial egg & $69.37 \pm 0.61^{\mathrm{a}}$ & $0.37 \pm 0.05^{\mathrm{a}}$ & $76.7 \pm 0.05^{\mathrm{a}}$ & $0.10 \pm 0.01^{\mathrm{b}}$ \\
$3^{\text {rd }}$ week & Village chicken egg & $66.59 \pm 0.39^{\mathrm{a}}$ & $0.39 \pm 0.00^{\mathrm{a}}$ & $75.7 \pm 0.00^{\mathrm{a}}$ & $0.08 \pm 0.01^{\mathrm{a}}-\cdots$ \\
& Commercial egg & $66.01 \pm 0.59^{\mathrm{a}}$ & $0.39 \pm 0.00^{\mathrm{a}}$ & $75.6 \pm 0.00^{\mathrm{a}}$ & $0.10 \pm 0.01^{\mathrm{b}}$ \\
\hline
\end{tabular}

Note. ${ }^{\mathrm{a}-\mathrm{b}}$ Means with different superscript in the same column were differ significantly $(P=0.05)$.

Shell thickness remained unchanged with the increased storage period regardless of species and in the meantime shell thickness value of commercial chicken egg showed significantly higher values than that of village chicken 
eggs (Table 2). Strains of the bird, diseases, housing management, age of the bird, drugs, water quality, environmental stress, hens' nutrition and egg weight influence the thickness of eggshell (Swaiatkiewicz et al., 2010). According to the Alsobayel and Albadry (2010) during storage period, eggshell thicknesses were remained unchanged. In addition to this, Samli el al. (2005) stated that eggs shell thickness values remain unchanged with increasing storage time and temperature.

According to the results of this study, gel strengths were increased with the increased storage period regardless of the chicken type. However, there was no significant difference found among gel strength value of the two different chicken groups (Table 3). Chang and Chen (2000) stated that $\mathrm{pH}$ of the food affects to the texture of the egg protein gel, meanwhile puffy gel coagulum was observed at $\mathrm{pH}$ values below 7.0. Hammershøj et al. (2002) found that texture of egg protein gel was affected by the prolong storage of eggs and during longer storage period, the ovalbumin that is responsible for egg coagulate is changed to it heat stable form (S-ovalbumin).

Table 3. Effect of storage on functional egg quality of village chicken eggs and commercial eggs (Means \pm SD)

\begin{tabular}{lllll}
\hline Storage Duration & & Gel strength $(\mathrm{N})$ & Viscosity $($ Centipoise) & Total color values $(\Delta \mathrm{E})$ \\
\hline \multirow{2}{*}{ Freshly laid egg 0 week } & Village chicken egg & $10.90 \pm 0.51^{\mathrm{a}}$ & $51.67 \pm 4.25^{\mathrm{a}}$ & $49.00 \pm 0.82^{\mathrm{a}}$ \\
& Commercial chicken egg & $11.40 \pm 0.34^{\mathrm{a}}$ & $36.33 \pm 3.57^{\mathrm{b}}$ & $46.93 \pm 1.89^{\mathrm{b}}$ \\
$1^{\text {st }}$ week & Village chicken egg & $11.37 \pm 4.58^{\mathrm{a}}$ & $17.17 \pm 1.65^{\mathrm{a}}$ & $48.33 \pm 0.47^{\mathrm{a}}$ \\
\hdashline & Commercial chicken egg & $10.93 \pm 2.87^{\mathrm{a}}$ & $15.33 \pm 0.47^{\mathrm{a}}$ & $47.47 \pm 0.82^{\mathrm{b}}$ \\
$2^{\text {nd }}$ week & Village chicken egg & $15.8 \pm 0.75^{\mathrm{a}}$ & $12.33 \pm 0.47^{\mathrm{a}}$ & $47.60 \pm 0.52^{\mathrm{a}}$ \\
$3^{3^{\text {rd }} \text { week }}$ & Commercial chicken egg & $15.00 \pm 0.24^{\mathrm{a}}$ & $10.33 \pm 0.47^{\mathrm{a}}$ & $47.81 \pm 1.44^{\mathrm{a}}$ \\
\hline
\end{tabular}

Note. ${ }^{\mathrm{a}-\mathrm{b}}$ Means with different superscript in two types of chicken in the same column were differ significantly $(P$ $<0.05)$.

A decreasing trend of viscosity was observed with increasing storage period regardless of the type (Table 3). Viscosity of the village chicken egg was significantly higher than that of commercial chicken eggs. Rheological property of the egg albumen is an important quality attribute that determines the other functional parameters such as emulsifying ability, whipping and gelling properties of the egg. Those are important in egg products industry (Kemp et al., 2010). According to the findings of Spada et al. (2012) viscosity value of Isa brown and Carijo Barbara strains were decreased with the storage period. Similar to present findings, Spada et al. (2012) found that within the same strain, significant difference in viscosity value of eggs with the storage period. In addition, Severa et al. (2010) stated that the time dependent viscosity value decreased with the storage period. Possible reason of decreasing viscosity with storage period is increasing of flow behavior index over temperature The albumen viscosity depends on ovomucin-lyzozyme complex. Therefore, decrease of albumen viscosity is due to destabilization of ovomucin-lysozyme structure. Moreover, increasing of $\mathrm{pH}$ during storage leads to destabilization of ovomucin complex. Finally, it causes to decrease the viscosity of the egg albumen (Spada et al., 2012).

The total color values $(\Delta \mathrm{E})$ obtained for village egg had significantly higher than that of commercial chicken egg (Table 3). Moreover, during storage time total color values were remained unchanged. The resulted highest total color value of village chicken eggs can be explained with the different diet eaten by village chickens. Color of the egg yolk is due to accumulation of pigments (Carotenoids) coming from the diet of the hen. Green materials such as corn, corn gluten, and marigold are the good sources of yellow colour pigments (Abiodun, 2014). Prolong storage time caused to decreased yolk color due to entering of water into the yolk through vitelline membrane. Water entered to the yolk dissolves the yolk pigments results decrease of yolk color (Jones et al., 2001; Wardy, 2010).

\section{Conclusions}

The egg quality characteristics showed a significant difference among the different poultry species. The SI and the HU were the highest in quail eggs. Whereas, the duck eggs had the highest viscosity and the gel strength among the different poultry species. Moreover, Sri Lankan village chicken eggs showed excellent egg yolk color compared with eggs from other poultry species used in this study. The HU, YI and viscosity values of Sri Lankan village chicken and Shaver brown chicken eggs decreased with the storage time. Meanwhile, gel strength was increased. However, SI, shell thickness, and colorant value remained unchanged during increase of egg storage 
period $\left(10^{\circ} \mathrm{C}\right)$. It can be concluded that egg quality is different among different poultry species and, are affected by the storage period.

\section{References}

Abiodun, B. S., Adedeji, A. S., \& Abiodun, E. (2014). Lesser known indigenous vegetables as potential natural egg colourant in laying chickens. Journal of Animal Science and Technology, 56(18), 1-5. https://doi.org/ 10.1186/2055-0391-56-18

Akyurek, H., \& Okur, A. A. (2009). Effect of storage time, temperature and hen age on egg quality in free-range layer hens. Journal of Animal Science and Veterinary Advance, 8(10), 1953-1958.

Alamprese, C., Casiraghi, E., \& Rossi, M. (2012). Foaming, gelling and rheological properties of egg albumen as affected by the housing system and the age of laying hens. International Journal of Food Science and Technology, 47(7), 1411-1420. https://doi.org/10.1111/j.1365-2621.2012.02988.x

Alkan, S., Karabag, K., Galic, A., Karsli, T., \& Balcioglu, M. S. (2010). Effects of selection for body weight and egg production on egg quality traits in Japanese quails (Coturnix coturnix japonica) of different lines and relationships between these traits. Journal of the Faculty of Veterinary Medicine, Kafkas University, 16(2), 239-244.

Alsobayel, A. A., \& Albadry, M. A. (2010). Effect of storage period and strain of layer on internal and external quality characteristics of eggs marketed in Riyadh area. Journal of the Saudi Society of Agricultural Sciences, 10(1), 41-45. https://doi.org/10.1016/j.jssas.2010.04.001

Altuntas, E., \& Sekeroglu, A. (2008). Effect of egg shape index on mechanical properties of chicken eggs. Journal of Food Technology, 85(4), 606-612. https://doi.org/10.1016/j.jfoodeng.2007.08.022

Anderson, E. K., Tharrington, J. B., Curtis, P. A., \& Jones, P. A. (2004). Shell characteristics of eggs from historic strains of single comb white leghorn chickens and relationship of egg shape to shell strength. International Journal of Poultry Science, 3(1), 17-19. https://doi.org/10.3923/ijps.2004.17.19

Benton, C. E., \& Brake, J. (2000). Effects of atmospheric ammonia on albumen height and $\mathrm{pH}$ of fresh broiler breeder eggs. Poultry Science, 79(11), 1562-1565. https://doi.org/10.1093/ps/79.11.1562

Chang, Y. I., \& Chen, T. C. (2000). Functional and gel characteristics of liquid whole egg as affected by pH alteration. Journal of Food Engineering, 45(4), 237-241. https://doi.org/10.1016/S0260-8774(00)00066-2

Cieck, T., \& Kartalkanat, A. (2009). Comparison of village chicken eggs and commercial eggs in terms of egg quality. Journal of Animal and Veterinary Advances, 8(12), 2542-2545.

Department of Animal Production and Health. (2015). Livestock Statistics-Key Statistics. Retrieved from $\mathrm{http} / /$ www.daph.gov.lk/web/index.php?option=com_content\&view=article\&id=119\&Itemid=108\&lang=en

Department of Animal Production and Health. (2020). Livestock Statistics-Key Statistics. Retrieved from http://www.daph.gov.lk/web/images/content_image/Livestock_stat/key_stat/2019/Poultry_2019.pdf

Duan, X., Li, M., Shao, J., Chen, H., Xu, X., \& Jin, Z. (2018). Effect of oxidative modification on structural and foaming properties of egg white protein. Food Hydrocolloids, 75(1), 223-228. https://doi.org/10.1016/ j.foodhyd.2017.08.008

Dudusola, I. O. (2009). Effects of storage methods and length of storage on some quality parameters of Japanese quail eggs. Tropicultura, 27(1), 45-48.

Dudusola, I. O. (2010). Comparative evaluation of internal and external qualities of eggs from quail and guinea fowl. International Research Journal of Plant Science, 1(5), 112-115.

Eke, M. O., Olaitan, N. I., \& Ochefu, J. H. (2013). Effect of storage conditions on the quality attributes of shell (Table) Eggs. Nigerian Food Journal, 31(2), 18-24. https://doi.org/10.1016/S0189-7241(15)30072-2

Elango, S., \& Mahendrarasa, R. (2013). Comparative analysis of the egg quality traits in different chicken genotypes in the dry zone of Sri Lanka (pp. 86-91). Proceedings of the $3^{\text {rd }}$ International Symposium, South Eastern University of Sri Lanka, Oluvil, Sri Lanka.

FAO. (2013). Food and Agriculture Organization Statistical Year Book 2013. FAO Statistical Division, Food and Agriculture Organization of United Nations, Rome.

FAOSTAT. (2015). Food and Agriculture Organization of United Nations Production Data. Retrieved from http://faostat.fao.org/site/291/default.aspx 
FAOSTAT. (2020). Food and Agriculture Organization of United Nations. Retrieved June 28, 2020, from http://www.fao.org/faostat/en/\#data/QL

Funk, E. M. (1948). The relation of the yolk index determined in natural position to the yolk index as determined after separating the yolk from the albumen. Poultry Science, 27(3), 376. https://doi.org/10.3382/ps.0270367

Gunarathne, S. P., Chandrasekara, A. D. N., Hemalatha, M., \& Roberts, J. A. (1993). Feed resource base for scavenging village chickens in Sri Lanka. Tropical Animal Health and Production, 25(4), 249-257. https://doi.org/10.1007/BF02250880

Hammershøja, M., Larsen, L. B., Andersen, A. B., \& Qvist, K. B. (2002). Storage of shell eggs influences the albumen gelling properties. LWT-Food Science and Technology, 35(1), 62-69. https://doi.org/10.1006/ fstl.2001.0811

Haugh, R. R. (1937). The Haugh unit for measuring egg quality. United State Egg Poultry Magazine, 43(5), 552-555; 572-573.

Houška, M., Kýhos, K., Novotná, P., Landfeld, A., \& Strohalm, J. (2004). Gel strength of the native egg white. Czech Journal of Food Sciences, 22, 58-66. https://doi.org/10.17221/3407-CJFS

Hristakieva, P., Oblakova, M., Mincheva, N., Lalev, M., \& Kaliasheva, K. (2017). Phenotypic correlations between the egg weight, shape of egg, shell thickness, weight loss and hatchling weight of turkeys. Slovak Journal of Animal Science, 50(2), 90-94.

Hrncar, C., Hanusova, E., Hanus, A., \& Bujko, J. (2014). Effects of genotype on egg quality characteristics of Japanese quail (Coturnix japonica). Slovak Journal of Animal Science, 47(1), 6-11.

Hussain, S., Ahmed, Z., Khan, M. N., \& Khan, T. A. (2013). A study on quality traits of chicken eggs collected from different areas of Karachi. Sarhad Journal of Agriculture, 29(2), 255-259.

Jalaludeen, A., \& Churchil, R. R. (2006). Duck eggs and their nutritive value. Poultryline, 10, 35-39.

Jones, D. R., Anderson, K. E., \& Davis, G. S. (2001). The effects of genetic selection on production parameters of single comb white leghorn hens. Poultry Science, 80(8), 1139-1143. https://doi.org/10.1093/ps/80.8.1139

Keener K. M., McAvoy, K. C., Foegeding J. B., Curtis P. A., Anderson, K. E., \& Osborne, J. A. (2006). Effect of testing temperature on internal egg quality measurements. Poultry Science, 85(5), 550-555. https://doi.org/ $10.1093 / \mathrm{ps} / 85.3 .550$

Kemp, B. J., Bamelis, F. R., Mertens, K., Decaypere, E. M., Baerdemaeker, J. G. D., \& Ketelaer, B. D. (2010). The assessment of viscosity measurements on the albumen of consumption eggs as an indicator for freshness. Poultry Science, 89(12), 2699-2703. https://doi.org/10.3382/ps.2008-00520

Kokoszynski, D., Bernacki, Z., \& Korytkowska, H. (2007). Eggshell and egg content traits in Peking duck eggs from the P44 reserve flock raised in Poland. Journal of central European Agriculture, 8(1), 9-16.

Kumbár, V., Strnková, J., Nedomová, Š., \& Buchar, J. (2015). Fluid dynamics of liquid egg products. Journal of Biological Physics, 41(3), 303-311. https://doi.org/10.1007/s10867-015-9380-5

Linden, G., \& Lorient, D. (1999). New ingredients in food processing: Biochemistry and agriculture. Woodhead Publishing Ltd., Abington, Cambridge, UK. https://doi.org/10.1201/9781439822760

Liu , X. D., Jang, A., Kim, D. H., Lee, B. D., Lee, M., \& Jo, C. (2009). Effect of combination of chitosan coating and irradiation on physiochemical and functional properties of chicken eggs during room-temperature storage. Radiation Physics and Chemistry, 78(7-8), 589-591. https://doi.org/10.1016/ j.radphyschem.2009.03.015

Lucisano, M., Hidalgo, A., Comelli, E. M., \& Rossi, M. (1996). Evolution of chemical and physical albumen characteristics during the storage of shell eggs. Journal of Agricultural and Food Chemistry, 44(5), 1235-1240. https://doi.org/10.1021/jf950485o

Marzec, A., Michalczuk, M., Damaziak, K., Mieszkowska, A., Lenart, A., \& Niemiec, J. (2016). Correlations between vitelline membrane strength and selected physical parameters of poultry eggs. Annals of Animal Science, 16(3), 897-907. https://doi.org/10.1515/aoas-2016-0015

Monira, K. N., Salahuddin, M., \& Miah, G. (2003). Effect of breed and holding period on egg quality characteristics of chicken. International Journal of Poultry Science, 2(4), 261-263. https://doi.org/10.3923/ ijps.2003.261.263 
Musa, T. N., Ulaiwi, W. S., \& Al-Hajo, N. N. A. (2011). The effect of Shellac as coating material on the internal quality of chicken eggs. International Journal of Poultry Science, 10(1), 38-41. https://doi.org/10.3923/ ijps.2011.38.41

Nepomuceno, R. C., Watanabe, P. H., Freitas, E. R., Braga, C. E. C., Peixoto, M. S. M., \& Sousa, M. L. D. (2014). Quality of quail eggs at different times of storage. Ciência Animal Brasileira, 15(4), 409-413. https://doi.org/10.1590/1089-6891v15i424107

Nikolova, N., \& Kocevski, D. (2006). Forming egg shape index as influenced by ambient temperature and age of hens. Biotechnology in Animal Husbandry, 22(1-2), 119-125. https://doi.org/10.2298/BAH0602119N

Nowaczewski, S., Kontecka, H., Rosiński, A., Koberling, S., \& Koronowski, P. (2009). Egg quality of Japanese quail depends on layer age and storage time. Folia Biologica, 58(3-4), 201-207. https://doi.org/10.3409/ fb58_3-4.201-207

Okruszek, A., Książkiewicz, J., Wołoszyn, J., Kisiel, T., Orkusz, A., \& Biernat. J. (2006). Effect of laying period and duck origin on egg characteristics. Archives Animal Breeding, 49(4), 400-410. https://doi.org/ 10.5194/aab-49-400-2006

Pelicia, K, Garcia, E. A., Faitarone, A. B. G., Silva, A. P., Berto, D. A., Molino, A. B., \& Vercese, F. (2009). Calcium and available phosphorus levels for laying hens in second production cycle. Brazilian Journal of Poultry Science, 11(1), 39-49. https://doi.org/10.1590/S1516-635X2009000100007

Raji, A. O., Aliyu, J., Igwebuike, J. U., \& Chiroma, S. (2009). Effect of storage methods and time on egg quality traits of laying hens in a hot dry climate. ARPN Journal of Agricultural and Biological Science, 4(4), 1-7.

Rodrigues, E. A., Junqueira, O. M., Valério, M., Andreotti, M. O., Cancherini, L. C., Faria, D. E., \& Filardi, R. S. (2005). Calcium levels in commercial laying hens in the second laying cycle. Acta Scientiarum, Animal Sciences, 27(1), 49-54. https://doi.org/10.4025/actascianimsci.v27i1.1240

Samli, H. E., Agma, A., \& Senkoylu, N. (2005). Effect of storage time and temperature on egg quality in old laying hens. Journal of Applied Poultry Research, 14(3), 548-553. https://doi.org/10.1093/japr/14.3.548

SAS Institute. (2009). SAS User's Guide. SAS Institute Inc., Cary, NC, USA.

Severa, L., Nedomova, S., \& Buchar, J. (2010). Influence of storing time and temperature on the viscosity of an egg yolk. Journal of Food Engineering, 96, 266-269. https://doi.org/10.1016/j.jfoodeng.2009.07.020

Sheng, L., Huang, M., Wang, J., Xu, Q., Hammad, H. H. M., \& Ma, M. (2018). A study of storage impact on ovalbumin structure of chicken egg. Journal of Food Engineering, 219(1), 1-7. https://doi.org/10.1016/ j.jfoodeng.2017.08.028

Song, K. T., Choi, S. H., \& Oh, H. R. (2000). A Comparison of egg quality of Pheasant, Chukar, Quail and Guinea fowl. Asian Australasian Journal of Animal Science, 13(7), 986-990. https://doi.org/10.5713/ ajas. 2000.986

Spada, F. M., Gutierrez, E. M. R., Souza, M. C. D., Brazaca, S. G. C., Lemes, D. E. A., Fisher, F. S., ... Savino, V. J. M. (2012). Viscosity of egg white from hens of different strains fed with commercial and natural additives. Ciência e Tecnologia de Alimentos, 32(1), 47-51. https://doi.org/10.1590/S0101-20612012005 000017

Stadelman, W. J. (1977). Quality identification of shell eggs. In W. J. Stadelman \& O. J. Cotterill (Eds.), Egg science and technology (pp. 29-40, 2nd ed.). The AVI Publishing Company, INC., Westport, Connecticut, USA.

Swaiatkiewicz, S., Koreleski, J., \& Arczewska, A. (2010). Laying performance and eggshell quality in laying hens fed diets supplemented with prebiotics and organic acids. Czech Journal of Animal Science, 55(7), 294-306. https://doi.org/10.17221/207/2009-CJAS

Tabidi, M. H. (2011). Impact of storage period and quality on composition of table egg. Advances in Environmental Biology, 5(5), 856-861.

Tadesse, D., Esatu, W., Girma, M., \& Dessie, T. (2015). Comparative study on some egg quality traits of exotic chicken in different production system in East Shewa, Ethiopia. African Journal of Agricultural Research, 10(9), 1016-1021. https://doi.org/10.5897/AJAR2014.9373 
Tan, T. C., Kanyarat, K., \& Azhar, M. E. (2012). Evaluation of functional properties of egg white obtained from pasteurized shell egg as ingredient in angel food cake. International Food Research Journal, 19(1), 303-308.

The Poultry Site. (2015). Global poultry trends—Strong Growth in Egg Output Recorded in Africa and Oceania. Retrieved from http://www.thepoultrysite.com/articles/3488/global-poultry-trends-strong-growth-in-egg-out put-recorded-in-africa-and-oceania

United State Department of Agriculture. (2000). Egg Grading Manual. Agricultural Handbook (No. 75). Agricultural Marketing Service, United States Department of Agriculture, Washington, USA.

Wardy, W., Torrico, D. D., No, H. K., Prinyawiwatkul, W., \& Saalia, F. K. (2010). Edible coating affects physico-functional properties and shelf life of chicken eggs during refrigerated and room temperature storage. International Journal of Food Science and Technology, 45(12), 2656-2668. https://doi.org/10.1111/ j.1365-2621.2010.02447.x

Wickramasinghe, Y. H. S. T., Vidanarachchi, J. K., \& Himali, S. M. C. (2015). Evaluation of quality attributes of chicken eggs available in supermarkets in Kandy district, Sri Lanka (pp. 150-158). Proceedings of the $3^{\text {rd }}$ International Research Symposium-2015, Rajarata University of Sri Lanka, Sri Lanka.

Xu, L., Jai, F., Luo, C., Yu, Q., Dai, R., \& Li, X. (2018). Unravelling proteome changes of chicken egg whites under carbon dioxide modified atmosphere packaging. Food Chemistry, 239(1), 657-663. https://doi.org/ 10.1016/j.foodchem.2017.06.128

Yuceer, M., \& Caner, C. (2014). Antimicrobial lysozyme-chitosan coatings affect functional properties and shelf life of chicken eggs during storage. Journal of the Science of Food and Agriculture, 94(1), 153-162. https://doi.org/10.1002/jsfa.6322

Zita, L., Ledvinka, Z., \& Klesalová, L. (2013). The effect of the age of Japanese quails on certain egg quality traits and their relationships. The Journal Veterinarski Arhiv, 83(2), 223-232.

Zita, L., Tůmová, E., \& Štolc, L.(2009). Effects of genotype, age and their interaction on egg quality in brown-egg laying hens. Journal of the University of Veterinary and Pharmaceutical Sciences in Brno, 78(1), 85-91. https://doi.org/10.2754/avb200978010085

\section{Copyrights}

Copyright for this article is retained by the author(s), with first publication rights granted to the journal.

This is an open-access article distributed under the terms and conditions of the Creative Commons Attribution license (http://creativecommons.org/licenses/by/4.0/). 